\title{
PAPPOPHORUM PHILIPPIANUM (GRAMINEAE) NEW TO NORTH AMERICA
}

\author{
John R. Reeder \& L. J. Toolin \\ Herbarium, University of Arizona, Tucson, AZ 85721
}

In his Mexican Grasses in the United States National Herbarium, H1tchcock (1913) listed three species of Pappophorum. One of these, P. Wrighti1 S. Wats.. is now excluded and assigned to the genus Enneapogon, as E. Desvaux11 P. Beauv. The other two names are Pappophorum laguroideum Schreb. $[=\underline{P}$. papplferum (Lam.) Kuntze] and $\underline{p}$. vaqinatum Buckley. Both of these names are current, and apply to species well documented as occurring in Mexico. In the above work there are keys to the genera and species, but no descriptions. The range for each species is given, however, and this is followed by a list of the specimens seen by the author. In the case of $\underline{P}$. vaginatum, several collections are cited from the states of Durango, Coahuila, Nuevo Lèn, and there is one from Guaymas, Sonora (Palmer 350 in 1887).

The Sonoran locality is separated from the others not only by a considerable distance, but also by the Sierra Madre Occidental which might seem to be a formidable barrier. Nevertheless, no one seemed to question Hitchcock's determination of the Palmer gathering until Swallen (1964) redetermined it as pappophorum subbulbosum Arechavaleta, originally described from Uruguay. Swallen's determination appears to have been accepted by all subsequent botanists. In his revised catalogue of the grasses of Mexico, Beetle (1987) includes this name and lists the locality as Sonora.

Since Sonora borders Arizona, and the floras have many similarities, the ARIZ herbarium is rich in Sonoran collections. Among them are several gatherings of Pappophorum, a number of which had been named $\underline{P}$. mucronulatum. These specimens would key out to P. subbulbosum in Swallen's 1964 treatment. Because we have some familiarity with South America Pappophorum, we realized that these Sonoran plants were not good p. subbulbosum. Rather, they represent a related species, P. Phillppianum L. Parodi, originally described from Mendoza, Argentina, and not previously reported from North America. The diagnostic features of this latter species are the long glumes, mostly $6--10 \mathrm{~mm}$, with awn points $1 \mathrm{~mm}$ or more in length, and densely pilose lemmas. Callus hairs are about twothirds as long as the lemma body, and the interior of the lemma also has prominent hairs on the upper part below the point from which the numerous $7--10 \mathrm{~mm}$ long awns diverge.

All specimens of Pappophorum from coastal Sonora which we have

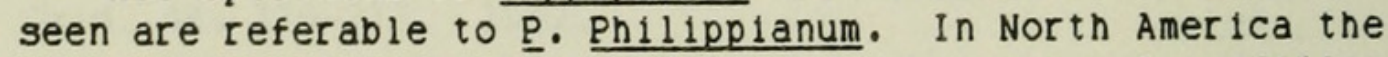
species appears to be limited to that area. In addition to the Palmer specimen mentioned above, the following collections, all from Sonora, Mexico, represent this species: 
Guaymas, 26 January 1927. ㅂ. E. Jones 23440. (M0-970023)

Bahia colorado, vicinity of $28^{\circ} 181 / 2^{\prime} \mathrm{N}$ lat.. $111^{\circ} 28^{\prime} \mathrm{W}$ long. Rocky hill, north side of Morro Colorado. 28--29 December 1966. Eelger, $\underline{\text { R. }}$ S. $\underline{\text { E. Hamllton }}$ 15703. (ARIZ-257056)

Estero Soldado, about $10 \mathrm{~km} \mathrm{E}$ of Bahia San Carlos; ca $100 \mathrm{~m} \mathrm{~N}$ of inland edge of estero; ecotone between saltscrub and desertscrub. Flat terrain, sandy-silty soll. Tufted perennial, locally common. 22 oct. 1984. Eelger, ‥ ‥ et al. 4-202. (ARIZ-252438)

Isla Almagre Chico in Guaymas Bay. $27^{\circ} 55^{\prime} \mathrm{N}$ lat.. $110^{\circ} 53^{\prime} \mathrm{W}$ long. Occasional perennial. Mostly on more level, open sites. 24 April 1985. Burgess. T. L.. ‥ ․ M. Turner \& J. E. Bowers 6912. (ARIZ-254841)

Puerto Viejo, $3.5 \mathrm{mi}$ S of El Paredoncito W $109^{\circ} 54^{\prime} 30^{\prime \prime}, \mathrm{N} 27^{\circ} 0^{\prime}$ 30". Rio Mayo, Shell mantled beach ridge to $8^{\prime}$ tall between mangroves, mud flats, and irrigated lands. 29 December 1985. Martin. $\underline{\text { P. S. }}$. $\underline{\text { M. }}$ K. O'Rourke S.n. (ARIZ-262162)

Dune behind beach at base of Punta Yavaros. Bayside of sand spit near mangroves. Less than $5 \mathrm{~m}$ elev. $109^{\circ} 26^{\prime} \mathrm{W}, 26^{\circ} 40^{\prime} 10^{\prime \prime} \mathrm{N}$.

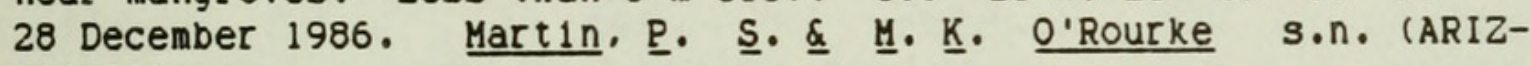
269151)

Pappophorum Philipplanum L. Parodi, Revista Mus, La Plata, Secc. Bot. 8(40): 79. 1943.

P. vaginatum Philipp1, Anales Univ. Chile 36: 206. 1870. non Buck 1ey, 1866.

P. papplferum (Lam.) Kuntze var. $\tau$ mucronulatum (Nees) Kuntze, Rev. Gen. P1. 3(3): 365. 1898.

P. mucronulatum Nees var. vaqinatum (Ph11.) Hackel in Stuckert, Gram. Arg. III, An. Mus. Nac. B. A1res 21: 123. 1911.

\section{LITERATURE CITED}

Beetle, A. A. 1987. Noteworthy grasses from Mexico XIII. Phytologia 63: 209--297.

H1tchcock, A. S. 1913. Mexican Grasses in the United States National Herbarium. Contr. U.S. Nat1. Herb. 17(3): 181--389+ index.

Swallen, J.R. 1964. Gramineae (1: 237--301) In: Shreve E. \& I. L. Wiggins, Vegetation and Flora of the Sonoran Desert. Stanford University Press. 


\section{$2 \mathrm{BHL}$ Biodiversity Heritage Library}

Reeder, John R and Toolin, Laurence J. 1988. "Pappophorum philippianum (Gramineae) new to North America." Phytologia 64, 402-403.

https://doi.org/10.5962/bhl.part.26121.

View This Item Online: https://www.biodiversitylibrary.org/item/46809

DOI: https://doi.org/10.5962/bhl.part.26121

Permalink: https://www.biodiversitylibrary.org/partpdf/26121

\section{Holding Institution}

New York Botanical Garden, LuEsther T. Mertz Library

\section{Sponsored by}

The LuEsther T Mertz Library, the New York Botanical Garden

\section{Copyright \& Reuse}

Copyright Status: In copyright. Digitized with the permission of the rights holder.

Rights Holder: Phytologia

License: http://creativecommons.org/licenses/by-nc-sa/3.0/

Rights: https://biodiversitylibrary.org/permissions

This document was created from content at the Biodiversity Heritage Library, the world's largest open access digital library for biodiversity literature and archives. Visit BHL at https://www.biodiversitylibrary.org. 